\title{
Device Intended But Not Used
}

National Cancer Institute

\section{Source}

National Cancer Institute. Device Intended But Not Used. NCI Thesaurus. Code C117758.

A status indicating that a device was introduced to the subject for use but did not meet its intended goal and was removed. 